\title{
Western Mountain Initiative: Predicting Ecosystem Responses to Climate Change
}

Mountain ecosystems of the western United States provide irreplaceable goods and services such as water, timber, biodiversity, and recreational opportunities, but their responses to climatic changes are complex and not well understood. Moreover, other ecological disturbances such as wildfire, insect outbreaks, and the spread of invasive species interact synergistically with warmer temperatures and accelerate ecosystem changes. The rate and magnitude of ecosystem responses to changes in the global atmospheric environment are variable and uncertain, ranging from gradual to abrupt and from moderate to profound. The responses of greatest importance to policy makers and land managers are also the least understood and least predictable: responses that are both abrupt and profound.

Scientists from several biology centers of the U.S. Geological Survey (USGS) and U.S. Forest Service are studying climate change and ecological interactions to better understand and predict likely outcomes in the mountainous American West. The Western Mountain Initiative (WMI) collaborates with U.S. Forest Service, National Park Service, and university partners that study global change in mountain ecosystems of the western United States. As part of the USGS Global Change Science program, the WMI seeks to understand and predict the responses-emphasizing sensitivities, thresholds, resistance, and resilience-of western mountain ecosystems to climatic variability and change.

WMI catalyzes assessment and synthesis of the effects of disturbance and climate change across western mountain areas, focusing on national parks and surrounding national

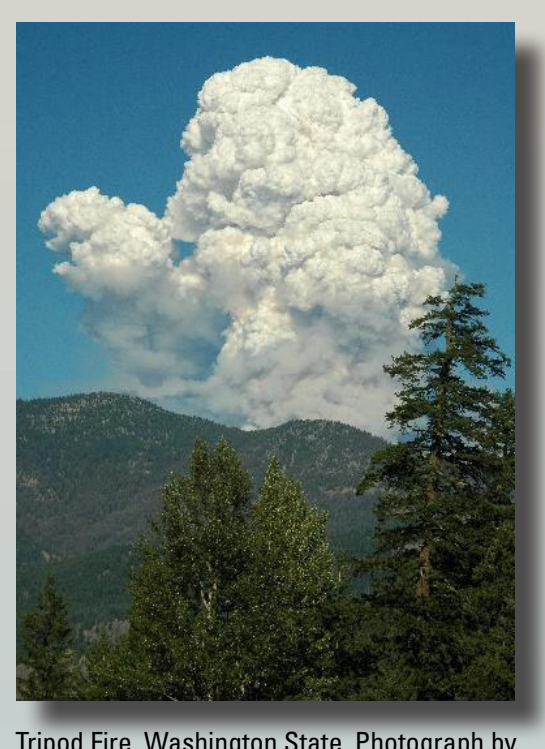

Tripod Fire, Washington State. Photograph by Philip Higuera, Montana State Univ. forests. WMI scientists nurture close working relationships with each other, the larger science community, and land and resource managers with whom they have cooperated for many years. They take an ecosystem approach to science, integrating research across science disciplines at scales ranging from field studies to global trends.

\section{WMI Accomplishments}

In addition to more than 170 published and in-press books, reports, and manuscripts, the WMI sponsors workshops, Web-based application and database development, and major collaborations. The following are recent examples:

\section{Workshops}

Fire History and Climate Synthesis in Western North America (2005)

As a result of this meeting of tree ring and charcoal specialists (http://www4.nau.edu/firehistory/index.htm), special symposia were held at the Third International Fire Ecology and Management Congress (San Diego, 2006) and the International Association for Landscape Ecology (Tucson, 2007). Proceedings compose a special issue of the International Journal of Wildland Fire (v. 17, no. 1) on "Fire Climatology" (see http://www.publish.csiro.au/nid/115/ issue/4151.htm).

State of Knowledge on Alpine Treeline Ecotones and Treeline Dynamics (2005)

This workshop of 35 leading treeline scientists is published as "Alpine Treeline of Western North America: Linking Organism-to-Landscape Dynamics": Malanson and others, Physical Geography (2007), v. 28, p. 378-396 (see http:// bellwether.metapress.com/content/gj25g46703607153/).
Climate Change and Disturbance Interactions in Western North America (2007)

Researchers in climatology, ecosystem science, fire and insect ecology, and landscape modeling integrated knowledge involving interactions among disturbance regimes that could accelerate ecosystem change. The workshop report is published as "Climate Change and Disturbance Interactions": McKenzie, D., and C.D. Allen, EOS, Transactions American Geophysical Union (2007), v. 88, no. 21, doi:10.1029/2007EO210010 (http://www.agu.org/pubs/ crossref/2007/2007EO210010.shtml)

\section{Web Sites and Web-based Applications}

CHARSTER software package manages and analyzes sedimentary charcoal data, improves data integration between studies, and facilitates geographic studies of paleofire and climate records. See http://geography.uoregon.edu/gavin/ charster/Introduction.html.

Glaciers Online: Glaciers of the American West provides interactive maps, photos, and data for these glaciers. See http://glaciers.research.pdx.edu/index.php.

RHESSys (Regional HydroEcological Simulation System) addresses the responses of western mountain ecosystems to climate change. RHESSys is a GIS-based hydroecological modeling framework that simulates water, carbon, and nutrient fluxes. See http://fiesta.bren.ucsb.edu/ rhessys/. 


\section{National/International Collaboration}

- The Consortium for Integrated Climate Research in Western Mountains (CIRMOUNT) brings together USGS, U.S. Forest Service, National Oceanic and Atmospheric Administration, and university scientists to improve understanding and integrate applications about climate in western mountains and effects on ecosystems. WMI scientists hold positions on the CIRMOUNT advisory board. See http://www.fs.fed.us/ psw/cirmount/.

- WMI partners cooperate with CORFOR, the Cordillera Forest Dynamics Network (North and South American mountains: see http://mri.scnatweb.ch/networks/ mri-amercian-cordillera/-cordillera-forest-dynamics-networkcorfor.html) and MRI, the Mountain Research Initiative, which tracks and addresses global change issues in mountain regions around the world. See http://www.mri.scnatweb.ch/.

\section{Leading Research Published on Forest Dynamics and Disturbance}

Climatic change, wildfire, and conservation: McKenzie and others, Conservation Biology (2004), v. 18, p. 890-902 (http://www.fs.fed.us/r6/fish/conservation-biology/05-fireclimatechange-2004.pdf).

Regional vegetation die-off in response to global-changetype drought: Breshears and others, Proceedings of the National Academy of Sciences (2005), v. 102, p. 1514415148 (http://www.pnas.org/content/102/42/15144.abstract).

Changing temperatures influence suitability for modeled mountain pine beetle (Dendroctonus ponderosae) outbreaks in the western United States: Hicke and others, Journal of Geophysical Research (2006), v. 111, G02019, DOI:10.1029/2005JG000101 (http://www.agu.org/pubs/ crossref/2006/2005JG000101.shtml).

Apparent climatically induced increase of tree mortality rates in a temperate forest: van Mantgem and others, Ecology Letters (2007), v. 10, p. 909-916, DOI:10.1111/

\section{WMI Online Resources}

Western Mountain Initiative (USGS Web site)

http://biology.usgs.gov/ecosystems/global_change/wmi.html Western Mountain Initiative

http://www.cfr.washington.edu/research.fme/wmi/index.htm USGS Global Change Program

http://www.usgs.gov/global_change/

Current Global Change Projects: Response of Western Mountain Ecosystems to Climatic Variability and Change-The Western Mountain Initiative http://biology.usgs.gov/ecosystems/global_change/western_mountain.html

MRI Newsletter 10: The Western Mountain Initiative (WMI)_More Than the Sum of Its Parts http://mri.scnatweb.ch/dmdocuments/MRI_Newsletter_ no10.pdf

Park Science: Response of Western Mountain Ecosystems to Climatic Variability and Change-The Western Mountain Initiative

http://www.werc.usgs.gov/seki/pdfs/WMI_Park\%20

Science_2006.pdf j.1461-0248.2007.01080.x (http://www.werc.usgs.gov/seki/ pdfs/van\%20Mantgem\%20\&\%20Stephenson\%202007.pdf).

Douglas-fir growth in mountain ecosystems: water limits tree growth from stand to region: Littell and others, Ecological Monographs (2008), v. 78, p. 349-368 (http://www. esajournals.org/doi/abs/10.1890/07-0712.1).

Spatial patterns of transpiration response to climate variability in a snow-dominated mountain ecosystem: Christensen and others, Hydrological Processes (2008), DOI:10.1002/hyp.696 (http://www3.interscience.wiley.com/ cgi-bin/fulltext/117883644/PDFSTART).

\section{Contact Information}

Craig Allen (craig_allen@ usgs.gov; USGS Fort Collins Science Center, Jemez Mountains Field Station)

Jill Baron (jill_baron@ usgs.gov; USGS Fort Collins Science Center, Colorado State University Natural Resource Ecology Laboratory)

Dan Fagre (dan_fagre@ usgs.gov; USGS Northern Rocky Mountain Science Center)

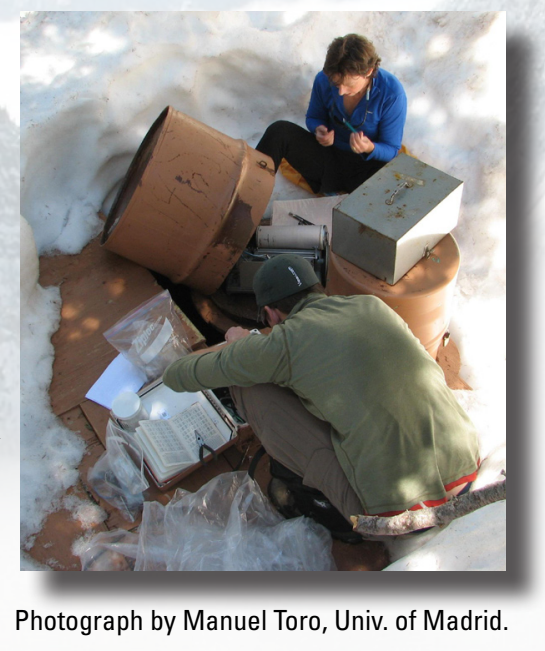

Don McKenzie (donaldmckenzie@fs.fed.us; U.S. Forest

Service, Pacific Northwest Research Station)

David Peterson (peterson@fs.fed.us; U.S. Forest Service,

Pacific Northwest Research Station)

Nate Stephenson (nstephenson@ usgs.gov; USGS Western Ecological Science Center)

\section{Select WMI Products}

Rocky Mountain Futures: An Ecological Perspective. Leading ecologists, geographers, and other scientists provide a comprehensive examination of the ecological consequences of past and current human activities in the Rocky Mountain region in North America. The authors project future effects based on current economic and social trends and emergent patterns. (J. Baron, ed., 2002, Island Press.)

Sustaining Rocky Mountain Landscapes: Science, Policy and Management of the Crown of the Continent Ecosystem. The authors offer a systematic, multidisciplinary assessment of the challenges involved in managing the Crown of the Continent Ecosystem, an area that includes northwestern Montana, southwestern Alberta, and southeastern British Columbia. (T. Prato and D. Fagre, eds., 2007, RFF Press)

Preliminary Review of Adaptation Options for Climate-Sensitive Ecosystems and Resources:

Final Report. (Science and Assessment Product 4.4 of the U.S. Climate Change Science Program.) WMI researchers were lead and contributing authors in this 2008 report, which identifies current and potential activities on public lands that can be used to prepare for climate-caused impacts on natural resources. Available at http://www. climatescience.gov/Library/sap/sap4-4/final-report/default. htm\#finalreport. 